\title{
The Effect of Online Learning on University Students' Learning Motivation
}

\author{
Hermiza Mardesci \\ Universitas Islam Indragiri, Tembilahan-Riau, Indonesia \\ Email:mimzaaci@yahoo.co.id
}

\begin{abstract}
This study was designed to determine the effect of online learning on students' learning motivation. Sixteen students from the Department of Food Technology, Islamic University of Indragiri, Indonesia, were involved in this study. Data collection was carried out through observation, literature review, and questionnaires. The results of this study indicate that students shared negative learning motivation responses to online learning.
\end{abstract}

Keywords: online learning, students' learning motivation

Coronavirus Disease (COVID-19) has massively impacted educational landscapes worldwide, including in the Indonesian education system. Anchored by this fact, the Indonesian government issued a policy through the Circular of the Minister of Cultural Education No. 3 of 2020 concerning the Prevention of Coronavirus Disease (COVID-19) in the Education Unit. As a follow-up to this circular, the Chancellor of the Islamic University of Indragiri, Indonesia, also issued an official letter addressed to the entire academic community regarding the precautionary approach. One of the approaches is to enact the teaching and learning processes using the online method as a substitute for face-to-face learning.

Based on several meetings in the implementation of online learning, it was seen that some of the students objected to learning with this method. Therefore, to find out the effect of online learning on students' learning motivation, further research is necessary. Several studies related to students' learning motivation have been carried out, including examining the effect of learning methods and learning motivation (Kawet, 2017), students' motivation toward learning process (Arianingsih \& Setianan, 2018), the impact of the internet on students' learning (Ricoida \& Pibriana, 2016), factors influencing students' learning motivation (Komariah, 2018), the role of learning media in improving students' learning motivation (Tafonao, 2018), computer-based learning media (Lutfi \& Nugroho, 2019) and many more. However, studies on the effect of online learning on university students' learning motivation are rarely conducted.

\section{METHOD}

Data were obtained through observation, review of related literature, and questionnaire dissemination. Sixteen students from Department of Food Technology, Islamic University of Indragiri, Indonesia, who are currently in the first and third years of study were recruited. The independent variable $(\mathrm{X})$ was online learning, and the dependent variable (Y) was students' learning motivation. Table 1 displays the questionnaire items.

The instrument was first validated to ensure its validity level. According to Arikunto (2013), a good instrument has a high level of validity and conversely. Valid instruments are able to measure what is desired and can reveal data from the variables being studied appropriately. For such a purpose, the Pearson Product Moment correlation formula was used in this study (Arikunto, 2013).

$$
\begin{aligned}
\mathrm{r}_{\mathrm{xy}}= & \frac{\mathrm{n} \sum \mathrm{X}_{\mathrm{i}} \mathrm{Y}_{\mathrm{i}}-\left(\sum \mathrm{X}_{\mathrm{i}}\right)\left(\sum \mathrm{Y}_{\mathrm{i}}\right)}{\sqrt{\left\{\mathrm{n} \sum \mathrm{X}_{\mathrm{i}}^{2}-\left(\sum \mathrm{X}_{\mathrm{i}}\right)^{2}\right\}\left\{\mathrm{n} \sum \mathrm{Y}_{\mathrm{i}}^{2}-\left(\sum \mathrm{Y}_{\mathrm{i}}\right)^{2}\right\}}} \\
& \text { Notes: } \\
& \mathrm{r}_{\mathrm{xy}} \quad=\mathrm{r}_{\text {count }} \text { (correlation coefficient) } \\
& \sum_{\mathrm{n}} \mathrm{X}_{\mathrm{i}}=\text { item score } \\
\mathrm{n} & =\text { score }=\text { number of respondents }
\end{aligned}
$$


Decision guideline for correlational study:

If $r_{\text {hitung }}>r_{\text {table }}$ so instrument is valid

If $r_{\text {hitung }}>r_{\text {table }}$ so instrument is not valid

In addition to the validity test, this study also tested the reliability of the research instrument. This test was carried out to see the accuracy and level of accuracy of the instruments used. Tests were carried out using the Cronbach Alpha coefficient as follows:

$$
\text { Cronbach's Alpha }=\left(\frac{\mathrm{Q}}{\mathrm{Q}-1}\right)\left(1-\frac{\sum \mathrm{S}_{\mathrm{qi}}^{2}}{\sum \mathrm{S}_{\mathrm{X}}^{2}}\right)
$$

Notes:

Q $\quad=$ number of items in one variable

$\mathrm{S}_{\mathrm{qi}}=$ score variance per item

$\mathrm{S}_{\mathrm{x}} \quad=$ variance of the total score for

items

formulated:

$$
\begin{array}{ll}
\sum_{\text {Notes: }} & \mathrm{S}_{\mathrm{qi}}^{2}=\frac{\sum \mathrm{X}^{2}-\frac{\sum(\mathrm{X})^{2}}{\mathrm{n}}}{\mathrm{n}} \\
\mathrm{S}_{\mathrm{qi}} \quad=\text { score variance per item } \\
\mathrm{X} \quad=\text { total item score } \\
\mathrm{n} \quad=\text { number of respondents }
\end{array}
$$

Whether or not a questionnaire or instrument is reliable can be seen from the Cronbach Alpha coefficient value. If the coefficient shows a number between $0.7-0.9$, it can be concluded that the instrument is reliable (Yusup, 2018).

Data analysis in this study used a simple linear regression analysis. However, before the data was processed by linear regression, the normality test was first carried out. This is necessary to determine whether the data are spread normally. If the data are spread normally, the

\begin{tabular}{|c|c|c|c|c|c|}
\hline No & Variable & Code & Indicator & Items & $\begin{array}{l}\text { Instru- } \\
\text { ment }\end{array}$ \\
\hline \multirow{8}{*}{1} & \multirow{8}{*}{$\begin{array}{l}\text { Perceived } \\
\text { Usefulness } \\
\text { of the } \\
\text { "online } \\
\text { learning" }\end{array}$} & $\mathrm{X}_{1}$ & $\begin{array}{l}\text { Online learning makes it easier for me to attend learning even } \\
\text { though I live far away in the area }\end{array}$ & 1 & 1 \\
\hline & & $\mathrm{X}_{2}$ & Studying online can save my energy in following learning & 1 & 2 \\
\hline & & $\mathrm{X}_{3}$ & Online learning can save me time in following learning & 1 & 3 \\
\hline & & $\mathrm{X}_{4}$ & Online tuition can save me money in attending learning & 1 & 4 \\
\hline & & $\mathrm{X}_{5}$ & $\begin{array}{l}\text { Online learning can make it easier for me to complete } \\
\text { assignments given by the lecturer }\end{array}$ & 1 & 5 \\
\hline & & $\mathrm{X}_{6}$ & $\begin{array}{l}\text { Online learning can improve my knowledge related to information } \\
\text { technology }\end{array}$ & 1 & 6 \\
\hline & & $\mathrm{X}_{7}$ & $\begin{array}{l}\text { Online learning can give me the opportunity to be able to do other } \\
\text { activities outside of class hours, especially activities to develop } \\
\text { my potential }\end{array}$ & 1 & 7 \\
\hline & & $\mathrm{X}_{8}$ & $\begin{array}{l}\text { Online learning can help me to continue to carry out social } \\
\text { distancing, physical distancing, and stay at home, according to } \\
\text { government advice amid the outbreak of the coronavirus }\end{array}$ & 1 & 8 \\
\hline \multirow{6}{*}{2} & \multirow{6}{*}{$\begin{array}{l}\text { Behavioral } \\
\text { Intention to } \\
\text { Use the } \\
\text { "online } \\
\text { learning" }\end{array}$} & $\mathrm{Y}_{1}$ & I am always excited about taking online learning for each subject & 1 & 9 \\
\hline & & $\mathrm{Y}_{2}$ & I prefer to study online than face to face & 1 & 10 \\
\hline & & $Y_{3}$ & $\begin{array}{l}\text { I am always more enthusiastic about doing assignments through } \\
\text { online learning than face-to-face }\end{array}$ & 1 & 11 \\
\hline & & $\mathrm{Y}_{4}$ & $\begin{array}{l}\text { I may always try to attend learning online on several occasions, } \\
\text { such as doing assignments with friends }\end{array}$ & 1 & 12 \\
\hline & & $Y_{5}$ & $\begin{array}{l}\text { I plan to propose to lecturers and the campus to conduct online } \\
\text { learning more often in the future }\end{array}$ & 1 & 13 \\
\hline & & $\mathrm{Y}_{6}$ & $\begin{array}{l}\text { I will use online learning in doing assignments, presentations, and } \\
\text { tutorials }\end{array}$ & 1 & 14 \\
\hline
\end{tabular}
statistics used are parametric statistics. If the data are not normally distributed, the statistics used are non-parametric statistics. The normality test in this study used the Kolmogorov-Smirnov formula.

Table 1. Research Instrument

After the normality test was carried out, then a simple regression analysis was carried out. The purpose of regression analysis is to determine the effect of each independent variable on the dependent variable (Sunyoto, 2016). Regression analysis in this study aims to obtain a regression equation that can be used to predict the shape of the effect of online learning on students' learning 
motivation in learning. The formula used for the regression test is:

$$
\widehat{Y}_{1}=a+b X_{i}
$$

To obtain the values of $a$ and $b$, the following formula is used:

$$
\mathrm{b}=\frac{\mathrm{n} \sum \mathrm{XY}-\sum \mathrm{X} \sum \mathrm{Y}}{\mathrm{n} \sum \mathrm{X}^{2}-\left(\sum \mathrm{X}\right)^{2}} \quad \mathrm{a}=\frac{\sum \mathrm{Y}-\mathrm{b} \sum \mathrm{X}}{\mathrm{n}}
$$

Notes:

$\mathrm{a}=$ cutting $\mathrm{Y}$ to the regression

lineb $=\mathrm{X}$ coefficient (regression coefficient)

$\mathrm{n} \quad=$ number of observations

To see the strength of the linear relationship between two variables that have been analyzed by regression, a correlation coefficient was used. The correlation coefficient was obtained from the correlation analysis. According to Sunyoto (2016), correlation analysis aims to test whether two variables (dependent and independent) have a strong relationship or not, whether the relationship is positive or negative. However, in this study, the Spearman Rank Correlation Test was used because the sample used in this study was less than 30 . To perform the Spearman Rank Correlation Test, the following formula was used:

$$
\rho=1 \frac{6 \sum b_{i}^{2}}{n\left(n^{2}-1\right)}
$$

Notes:

$$
\begin{array}{ll}
\rho & =\text { rho }(\text { spearman correlation) } \\
\mathrm{n} & =\text { number of samples }
\end{array}
$$

The correlation coefficient can be positive or negative, ranging from -1.00 to 1.00 . A positive correlation coefficient indicates a parallel relationship, while a negative correlation coefficient indicates an inverse relationship. The correlation coefficient category based on the level of the relationship can be seen in Table 3 .

Table 3. Correlation Coefficient Category

\begin{tabular}{|l|l|}
\hline Correlation Interval & Relationship Level \\
\hline $0.00-0.199$ & Very Low \\
\hline $0.20-0.399$ & Low \\
\hline $0.40-0.599$ & Moderate \\
\hline $0.60-0.799$ & Strong \\
\hline $0.80-1.000$ & Very Strong \\
\hline
\end{tabular}

\section{RESULTS AND DISCUSSION}

The results of testing the validity of the usability instrument (online learning) can be seen

\begin{tabular}{|c|c|c|c|}
\hline Statement & $r_{\text {count }}$ & $r$ table & Decision \\
\hline 1 & 0.829 & \multirow{8}{*}{0.497} & Valid \\
\hline 2 & 0.793 & & Valid \\
\hline 3 & 0.564 & & Valid \\
\hline 4 & 0.749 & & Valid \\
\hline 5 & 0.591 & & Valid \\
\hline 6 & 0.641 & & Valid \\
\hline 7 & 0.534 & & Valid \\
\hline 8 & 0.621 & & Valid \\
\hline
\end{tabular}
in Table 4, while the results of testing the validity of the learning motivation instrument can be seen in Table 5.

Table 4. Online Learning Instrument Validity

Table 5. Motivation Instrument Validity

\begin{tabular}{|l|l|l|l|}
\hline Statement & $\mathrm{r}$ count & $\mathrm{r}$ table & Decision \\
\hline 9 & 0.601 & & Valid \\
\hline 10 & 0.930 & & Valid \\
\cline { 1 - 1 } & & \multirow{3}{*}{0.497} & Valid \\
\hline 11 & 0.619 & & Valid \\
\hline 12 & 0.952 & & Valid \\
\hline 14 & 0.560 & & Valid \\
\hline
\end{tabular}

In Tables 4 and 5, it can be seen that the results of testing the validity of this research instrument show that $r_{\text {hitung }}>r_{\text {table. This means that }}$ the instrument used is valid. The instrument validity coefficient in this study ranged from 0.534 to 0.952 . According to Yusup (2018), the higher the value of the coefficient of the validity of an instrument, the better the instrument.

Furthermore, the reliability test was carried out on the research data. Reliability testing is done to test whether the research instrument is accurate or not. The results of reliability testing on usability instruments (online learning) using the Cronbach's Alpha formula can be seen in Table 6, while the results of reliability testing on the instrument of learning motivation can be seen in Table 7. 
Table 6. Online Learning Instrument Reliability

\begin{tabular}{|c|c|c|c|c|c|c|}
\hline Statement & $Q$ & $\begin{array}{r}\text { Score per item } \\
\qquad\left(\boldsymbol{s}_{\boldsymbol{q} i}\right)\end{array}$ & $\begin{array}{c}\text { Total Score } \\
\qquad\left(S_{X}^{2}\right)\end{array}$ & $\begin{array}{l}\text { Cronbach's } \\
\text { Alpha }\end{array}$ & Criteria & Note \\
\hline 1 & \multirow{8}{*}{8} & 0.6625 & \multirow{8}{*}{15.6} & \multirow{8}{*}{0.8156} & \multirow{8}{*}{$\begin{array}{l}0.70- \\
0.90\end{array}$} & \multirow{8}{*}{ Reliable } \\
\hline 2 & & 0.9167 & & & & \\
\hline 3 & & 0.5167 & & & & \\
\hline 4 & & 0.8958 & & & & \\
\hline 5 & & 0.7333 & & & & \\
\hline 6 & & 0.2500 & & & & \\
\hline 7 & & 0.1958 & & & & \\
\hline 8 & & 0.2958 & & & & \\
\hline & $S_{q i}^{2}$ & 4.4667 & & & & \\
\hline
\end{tabular}

Table 7. Motivation Instrument Reliability

\begin{tabular}{|c|c|c|c|c|c|c|}
\hline Statement & Q & $\begin{array}{l}\text { Score per } \\
\text { item } \\
\qquad\left(S_{q i}\right)\end{array}$ & $\begin{array}{l}\text { Total } \\
\text { Score } \\
\qquad\left(S_{X}^{2}\right)\end{array}$ & Cronbach's Alpha & Criteria & Note \\
\hline 1 & \multirow{6}{*}{6} & 0.7625 & \multirow{6}{*}{18.6667} & \multirow{6}{*}{0.8464} & \multirow{6}{*}{$0.70-0.90$} & \multirow{6}{*}{ Reliable } \\
\hline 2 & & 1.4667 & & & & \\
\hline 3 & & 0.7833 & & & & \\
\hline 4 & & 0.1958 & & & & \\
\hline 5 & & 1.3625 & & & & \\
\hline 6 & & 0.9292 & & & & \\
\hline & $S_{q i}^{2}$ & 5.5000 & & & & \\
\hline
\end{tabular}

In Tables 6 and 7, it can be seen that the Cronbach's Alpha value on both instruments lies between $0.70-0.90$. It can be concluded that the two instruments in this study are reliable, since the Cronbach's Alpha value shows a number between $0.7-0.9$, it can be concluded that the instrument is reliable (Yusup, 2018). Thus, the instrument (questionnaire) can be used for research.

The normality test was carried out to understand whether the data obtained are normally distributed. The normality test that is sought by the Kolmogorov-Smirnov test shows that the largest |FT - FS | value in the online learning instrument is 0.1818 , and the learning motivation instrument is 0.9318 . Meanwhile, the Kolmogorov-Smirnov table value is 0.327 . This means that the data on the online learning instruments are normally distributed, and the data on the learning motivation instruments are not normally distributed. If the data are not normally distributed, the statistics used are nonparametric statistics.

Furthermore, a simple regression analysis is carried out to see the effect of online learning on students' learning motivation. The results of the regression calculations in this study can be seen in Table 8 . 
Table 8. Regression Analysis

\begin{tabular}{|c|c|c|c|c|}
\hline \multicolumn{5}{|l|}{ SUMMARY OUTPUT } \\
\hline \multicolumn{2}{|l|}{ Regression Statistics } & & & \\
\hline Multiple R & 0.680 & & & \\
\hline R Square & 0.462 & & & \\
\hline Adjusted R Square & 0.424 & & & \\
\hline Standard Error & 3.280 & & & \\
\hline \multirow[t]{2}{*}{ Observations } & 16.000 & & & \\
\hline & Coefficients & Standard Error & $t$ Stat & $P$-value \\
\hline Intercept & -3.564 & 6.272 & -0.568 & 0.579 \\
\hline Daring & 0.744 & 0.214 & 3.468 & 0.004 \\
\hline
\end{tabular}

In Table 8 , it can be seen that the $\mathrm{R}$ square (R2) value in the data of this study is 0.462 . This means that the multiple coefficients of determination in this study shows that only 0.462 or $46.2 \%$ of students' learning motivation in learning is influenced by online learning, while the rest is influenced by other variables not discussed in this study. In addition, in Table 8 , it can be seen that the regression coefficient is -3.564 , and the value of the $\mathrm{Y}$ variable is 0.7444 . Thus, the regression equation is obtained as follows:

$$
\widehat{\mathrm{Y}}=0,744-3,564 \mathrm{X}
$$

The regression equation states that if there is no decrease from variable $\mathrm{X}$, then the value of variable $\mathrm{Y}$ is 0.744 . A regression coefficient of 3.564 states that every reduction (-) of one value in variable $\mathrm{X}$ will increase the score of 0.744 . Meanwhile, the results of the Spearman Rank Correlation Test with the number $\mathrm{n}=16$, and bi2 $=234$, showed the Spearman correlation coefficient (rho) of 0.656. This means that the strength of the relationship between the dependent variable and the independent variable is of strong value, which ranges from 0.6 to 0.799 .

The results of this study indicate that online learning has an influence on students' learning motivation. However, the effect here shows a negative relationship between the two variables. This can be seen from the negative regression coefficient value. It can be concluded that if online learning increase, students' learning motivation in learning will decrease.

Learning motivation is a person's liking or learning motivation in learning or liking a lesson. This is in accordance with Slameto's (2010) research, which contends that learning motivation is a feeling of preference and attraction. Learning motivation increases because it affects learning achievement and outcomes (Nurhasanah \& Sobandi, 2016; Putri, Djaja, \& Suyadi, 2017; Rusmiati, 2017). However, learning motivation is also influenced by several factors, such as the environment, motivation, teaching staff, and also facilities (Astutik \& Ratih, 2014). In relation to this, learning motivation is influenced by the learning method which is conducted online or online. This is inseparable from the facilities and costs that must be incurred to take courses online.

Previous studies (see Mustofa, Chodzirin, \& Sayekti, 2019) indicated that online learning can suppress disparities in the quality of higher education. This can be done by leading universities to universities in the region. In addition, according to Kuntarto (2017), the online learning model is also effective because it is not limited to time and place to study. However, for certain conditions, studying online makes it difficult for students, especially those who live far away in the regions. This is related to the availability of networks such as the internet, LAN, WAN which is inadequate, and also the need for more data packets than usual. 


\section{CONCLUSION}

Online learning conducted in the midst of the COVID-19 pandemic has a negative influence on students' learning motivation. This form of negative relationship can be caused by several factors related to the implementation of online learning. As it is observed, online learning requires network facilities such as internet, LAN, and WAN. In certain areas, this network condition is insufficient to carry out online learning. Further research is needed to determine the factors that cause reduced students' learning motivation related to the implementation of online learning.

\section{REFERENCES}

Arianingsih, A., \& Setianan, S.M. (2018). Minat Belajar Mahasiswa terhadap Pembelajaran Chookai. Journal of Japanese Language Education \& Linguistics, Vol.2(2), 249-257.

Arikunto, S. (2013). Prosedur Penelitian: Suatu Pendekatan Praktik. Jakarta: Rineka Cipta.

Astutik, V.Y., \& Ratih, E. (2014). Faktor-Faktor yang Mempengaruhi Minat Belajar Pemeriksaan Fisik di Laboratorium pada Mahasiswa Akademi Kebidanan Wira Husada Nusantara Malang. Jurnal Universitas Tribhwuana Tunggadewi, Vol.2(1), 9-14.

Kawet, R.S.I. (2017). Pengaruh Metode Pembelajaran dan Minat Belajar Mahasiswa terhadap Hasil Belajar Manajemen Konstruksi. Jurnal Teknologi Pendidikan, Vol.19(3), 224-238.

Komariah, S. (2018). Faktor-Faktor yang Mempengaruhi Minat Belajar Mahasiswa.

Kuntarto, E. (2017). Keefektifan Model Pembelajaran Daring dalam Perkuliahan Bahasa Indonesia di Perguruan Tinggi. Journal Indonesian Language Education and Literature, Vol.3(1), 99-110.

Lutfi, A., \& Nugroho, A. (2019). Minat Belajar dan Keberhasilan Belajar Partikel Penyusun Atom Dengan Media Pembelajaran Permainan
Chem Man. J-PEK (Jurnal Pembelajaran Kimia), 4(1), 39-50.

Mustofa, M.I., Chodzirin, M., \& Sayekti, L. (2019). Formulasi Model Perkuliahan Daring sebagai Upaya Menekan Disparitas Kualitas Perguruan Tinggi. Walisongo Journal of Information Technology, Vol.1(2), 151-160.

Nurhasanah, S., \& Sobandi, A. (2016). Minat Belajar sebagai Determinasi Hasil Belajar Siswa. Jurnal Pendidikan Manajemen Perkantoran, Vol.1(1), 128-135.

Putri, K., Djaja, S., \& Suyadi, B. (2017). Pengaruh Minat Belajar dan Kecerdasan Emosional terhadap Prestasi Belajar Siswa Kelas XI IPS SMA Negeri 1 Prajekan Kabupaten Bondowoso Tahun Ajaran 2016/2017. Jurnal Pendidikan Ekonomi: Jurnal Ilmiah Ilmu Pendidikan, Ilmu Ekonomi, dan Ilmu Sosial, Vol.11(1), 67-74.

Ricoida, D.I., \& Pibriana, D. (2016, 1 November). In Pengaruh Internet terhadap Minat dan Perilaku Belajar Mahasiswa (pp. 281-288). Paper presented at the Seminar Nasional Sistem Informasi.

Rusmiati. (2017). Pengaruh Minat Belajar terhadap Prestasi Belajar Bidang Studi Ekonomi Siswa MA Al Fattah Sumbermulyo. UTILIY: Jurnal Ilmiah Pendidikan dan Ekonomi, Vol. 1(1), 21-36.

Slameto. (2010). Belajar dan Faktor-Faktor yang Mempengaruhinya. Jakarta: PT. Rineka Cipta.

Sunyoto, D. (2016). Metodologi Penelitian Akuntansi. Bandung: PT. Refika Aditama.

Tafonao, T. (2018). Peranan Media Pembelajaran dalam Meningkatkan Minat Belajar Mahasiswa. Jurnal Komunikasi Pendidikan, Vol.2(2), 103-114.

Yusup, F. (2018). Uji Validitas dan Reliabilitas Instrumen Penelitian Kuantitatif. Jurnal Tarbiyah: Jurnal Ilmiah Kependidikan, Vol.7(1), 17-23 